86. ten Bokkel Huinink WW (1996) Controlled multicenter study of the influence of two different dosages of subcutaneous rhEPO on the development of anemiat and transfusion dependency in patients witl ovarian carcinoma treated with platinum based combination chemotherapy. In: Smyth JF, Boogacrts MA, Ehmer BRM (eds) rhErythropoietin in Cancer Supportive Treatment. Marcel Dekker, New York, pp 99-112

87. Thatcher $N(1998)$ Management of chemotherapy-induced anemia in solid lumors. Semin Oncol 25 (Suppl 7): 23-26

88. Thatcher N De Campos ES Bell DR Steward WP Varghesc G Morann R, Vanstecukiste JF, Rosso R. Ewers SB. Sundal E, Schatzmann E, Stocker II (1909) Epoetin alpha prevents anacmia and recluces Iransfusion requirentents in pationts unclergoing primatrily platinum-based chemotherapy for smatl cell lung cincer. Br J Cancer $8(0): 396-402$

89. Tomida $\triangle$. Tsuruo T (f99)) Drug resistance mediated by edlular stress response to the mieroenvironment of solid tumors. Anticancer Drug Des 14: 169-177

9(). Tsukuda M, Mochinatsu I, Nagahara T, Kokalsu T, Sawaki S. Kubota A. Furkawa M. Arai Y (1993) Clinical application of recombinant human erythropoietin for trealments in patients with heald and neck cancer. Cancer lmumumol Immunother 36: 52-56

91. Tsurumi H, Yamada T, Hara T, Murakami N, Moriwaki H. Muto Y (1996) Transformation of aplastic anemia to acute myeloid leukemia with myclofibrosis following treatment with granulocyle colony-stimulating lactor and erythropoietin]. Rinsho Ketsueki 37: 630-632

92. Voigtmann R, Nowrousian MR, Essers U, Clemens M, Heidemann E, Mittermüller F, Quarder $O(1996) \mathrm{rl} E \mathrm{EPO}$ in the treatment of anemia associated with malignancy. In: Smyth JF, Boogaerts MA, Ehmer BRM (eds) rhErythropoictin in Cancer Supportive Treatment. Marcel Dekker, New York, pp 11.3-127

93. Young SD, Hill RP (1990) Eflects of reoxygenation on cells from hypoxic regions of solid tumors: anticancer drug sensitivity and metastatic potential. $J$ Natl Cancer Inst 82: 371-80)

94. Westenfelder C, Baranowski RL (2000) Erythropoictin stimulates probiferation of human renal carcinoma cells. Kidney Int 58: $647-6,57$

95. Wiltshaw E. Kroner T (1976) Phase II study of cis-dichlorodiammineplatinum

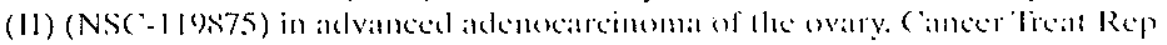
(6): $5.5-(n)$

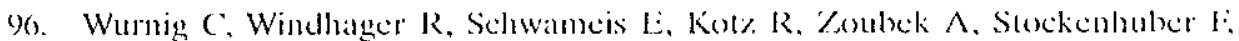
Kurz. RW (1996) Prevention of chemollarapy-induced anemia hy the ase of erybropoietin in patients with primary maligname bone tumors (a clouble-tidind. randomized, phase III study) Translusion 36: 155-159

97. Zachec P (1995) Controversies in selection of epoetin dosages. Issues and answers. Drugs 49: 536-547

Correspondence: Prof. Dr. M. R. Nowrousian, Department of Internal Medicine (Cancer Research), West German Caneer Center, University of Essen Medical School, Hufelandstrasse 55, D-45122 Essen, Germany (E-mail: nowrousian@uni-essen.de).

\section{Predictive factors for response of anemia to recombinant luman erythropoietin}

\author{
Y. Beguin
}

Y.I3. is Rescirch 1)irector of the National liund for Scientilic Research (FNRS, Belgium)

Department of Medicine, Division ol Hematology, University of Liège, Liegre. Belgium

\section{Introduction}

Patients with solid tumors or hematological malignancies often develop anemia at diagnosis or in the course of the disease (Means et al. 1992; Beguin 1996; Moliterno et al. 1996; Groopman et al. 1999). Many studies have shown that recombinant human erythropoietin (rHEpo) therapy can ameliorate the anemia associated with cancer and chemotherapy, reduce the need for transfusions and improve quality of life as well as work capacity. However, as many as $30-50 \%$ of the patients do not respond, even to very high doses of rHEpo. It is, therefore, important to be able to recognize and correct condilions adverscly affecting response to rHEpo, in particular functional iron deficiency. When no such particular condition can be identified, it would also be of great interest to have at one's disposal predictive algorithms of response. Thereby patients can be selected on the basis of their probability lo achieve a good response to treatment and prolonged ineffective use of an expensive medication can be avoided in those patients with a low probatbility ol response. In this paper, we will review factors potentially alfecting response to rFEpo and comment on the use of predictive algorithms.

\section{Factors influencing response to rHuEpo}

\section{Criteria of response}

Before analyzing factors potentially affecting response to $\mathrm{rHEpo}$, it is critical to define response criteria. Various trials in miscellaneous indications have employed very different response criteria. Trials employing less stringent criteria for defining response are very likely to report better outcome. 
Therefore, uniform response criteria should be proposed for transfused and untransfused, severely or not severely anemic cancer patients. However, these criteria should necessarily be partly different when rHEpo is used for the prevention or the treatment of anemia (Table 1). Prevention means that rHEpo is used in a nonanemic patient to avert the occurrence of anemia after chemotherapy or other interventions. Treatment signifies that rHEpo is given to reverse an anemia present at diagnosis or developing in the course of the disease. Complete response should be delined by the absence of anemia, i.c. maintenance (prevention) or achievement (trealment) of normal hematocrit. When treating an anemial, a major response delineantes the achicvement of a significant improvement approaching a normal situation, whereals a minor response corresponds (o a measurable though less dramatic effect: a major response can be defined by the abolition of transfusion needs and a hematocrit increment greater than 6 percentage points and

Table 1. Criteria of response to rHEpo

Treatment of anemia

- Complete response

- Normalize Hct/Hb value

- Major response: all criteria should be fulfilled

- No transfusion requirement

- Het increment $\geq 6 \%$ (Hb increment $\geq 2 \mathrm{~g} / \mathrm{dl}$ )

- Achicve $\mathrm{Hct} \geq 30 \%$ ( $\mathrm{Hb} \geq 10 \mathrm{~g} / \mathrm{dl}$ )

- Minor response: one criterion

- Decrease of 1 ransfusion needs $\geq 50 \%$

- Hct increment $\geq 6 \%$ but $\mathrm{Hct}<30 \%$ ( $\mathrm{Hb}$ increnent $\geq 2 \mathrm{~g} / \mathrm{dl}$ but $\mathrm{Hb}<10 \mathrm{~g} / \mathrm{dl}$ )

- Achieve Hct $\geq 30 \%$ but Hct increment $<6 \%$ ( $\mathrm{Hb} \geq 10 \mathrm{~g} / \mathrm{dl}$ but $\mathrm{Hb}$ increment $<2 \mathrm{~g} / \mathrm{dl})$

- Failure: one critcrion

- Decrease of transfusion needs $<.50 \%$

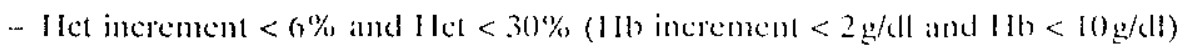

Prevention of anemia

- Complete responsc

- Maintain normal Het/Hb value

- Major response: all criteria shomld be fulfilled

- No transfusion requirement

- Hct decrement $<6 \%$ (Hb decrement $<2$ g/dl)

- Minor response: all criteria should be fulfilled

- No transfusion requirement $[\mathrm{Hb} \geq 8 \mathrm{~g} / \mathrm{dl}]$

- Het decrement $\geq 6 \%$ (Hb decrement $\geq 2 \mathrm{~g} / \mathrm{dl}$ )

- Failure:

- Transfusion $[\mathrm{Hb}<8 \mathrm{~g} / \mathrm{dl}]$ achievement of a hematocrit higher than $30 \%$; a minor response corresponds to only one of the two last criteria or a reduction of transfusion requirements by at least $50 \%$. When rHEpo is given to prevent anenia, a major response corresponds to a drop of the hematocrit by less than 6 percentage points and a minor response 10 a larger drop in hematocrit but without need for transfusion $(\mathrm{Hb}>8 \mathrm{~g} / \mathrm{dl})$.

\section{Treament schedule's}

Varying rates of response 10 rll apo among studies also reflect differences in dose, frepuency and route of administration, duration of therapy and the form of erythropoictin used (lable 2).

There is a clear dose-response effect with rHEpo and most studies in cancer patients have used doses in the range of $300-900 \mathrm{U} / \mathrm{kg} / \mathrm{wk}$, well above those given to renal failure patients. For instance, treatment of anemia in patients with advanced gastrointestinal cancer was much more successful with $10000 \mathrm{U}$ compared with $2000 \mathrm{U}$ t.i.w. (Glimelius et al. 1998). Similarly, daily doses of $5000 \mathrm{U}$ were more effective than lower doses and $10000 \mathrm{U}$ did not bring about further improvement in anemic patients with myeloma or lymphoma (Cazzola et al. 1995). The more convenient subcutaneous route of administration has been shown to ensure more favorable pharmacokinetics (Macdougall et al. 1989) that translates into higher efficacy in renal failure patients (Paganini et al. 1995). Most trials administered rHEpo thrice weekly, a schedule demonstrated to be more efficient than daily injections in normal subjects (Breymann et al. 1996). In normal volunteers treated for one month, weekly injections have been shown to produce crythropoietic responses similar to those achieved with t.i.w. schedules (Cheung et al. 2000). Although once-weekly dosing has been shown to increase $\mathrm{Hb}$, decrease transfusions and improve quality of life in a fashion analogous to what is obtained with thrice-weekly administration (Gabrilove et al. 2000), the equivalence of the livo schedules remains to be proven in prospective trials.

Whereas there is no known differenee in the efficacy and safety profile of Epretin- $\alpha$ (Janssen-Cilag), Epoetin- $\beta$ (Roche) or gene-activated Epoetin (Avemtis), novel long-acting erythropoiction molecules maly also considerably prolong exposure to the active drug and thus improve the efficacy of therapy with fewer injections. One of these molecules, named novel-erythropoiesis stimulating protein (NESP) or darbepoietin alfa (Amgen), has already been tested in prospective clinical trials in renal failure or cancer patients (Macdougall 2000).

The duration of treatment is of critical importance. In the largest trial published so far, whercas there was no significant difference in the rate of lransfusions between placebo and rHEpo-treated patients during the first month of therapy, the difference became highly significant during the second 
Table 2. Fictors potentially limiting response to rlll:po

\begin{tabular}{ll}
\hline Factor Factor Comments \\
influences \\
response \\
$\frac{\text { significantly }}{\text { Yes No }}$ \\
\hline
\end{tabular}

Fictors relating to rHEpo dreatment

- Dose

- Route

- Prequency

- Duration

- Type of rHEpo

Factors relating to the paticnt

- Age

- Sex

Factors relating to the discase

- Type of cancer

- Marrow infiltration

- Mechanisms of anemia Hemolysis

Blecding

Hypersplenism

Marrow necrosis or fibrosis

Hemophagocytosis Folate, B12, iron deficiency $\times$

Factors relating to chemotherapy

- Type of chemotherapy

Platinum vs non-platinum

intensity of chemotherapy

- Previous stem cell damage

- Complications

Infection

Inllammation

Blecding

- Surgery

Functional iron deficiency

- Caused by ACD

- Induced by rHEpo therapy

At least 1.50(t/kg lidw.

$S C^{\prime}>$ IV

×? Weckly $z$ 1.i.w. ?

$x \quad$ Needs al least 2-3 momblis

$\times \quad$ Long-acting Epo: less frequent dosing $\times \quad$ Unless massive (acute leukemia)

$\times$

$\times$

$x$
Nol clfective if intensified

chemotherapy

Low platelet count

Bleceling + impaired iron relcase

A major cantse of treatment failure and third months of treatment (Abch l\%2). In that trial also, the eflicacy of rHEpo appeared to be lower in cancer patients not treated with chemotherapy because erythropoietin was given for a shorter duration (and at a lower dose). This is due to the fact that expansion of the erythropoietic marrow in response to rHEpo is very gradual and achicves maxinum activity only after several weeks of treatment (Beguin et al. 1995). The response rate can thus be further improved when patients are treated for 6 months or more (Henry et al. 1994). In order to maximize "time with response", it would be desirable to achieve a faster response. Whether this can be achieved without fotal cost increase by providing higher doses of rellepo for a short period of lime (e.g. one month) followed by lower mantenane doses remains to be demomstraled.

\section{Discerse-associated factors}

A number of mechanisms can be involved in the pathogenesis of anemia associated with cancer (Means et al. 1992; Beguin 1996; Moliterno et al. 1996) and, therefore, interfere with response to rHEpo in individual patients (Table 2). Red cell loss may result from hypersplenism, blood losses consecutive to hemorrhage or iatrogenic phlebotomy, and autoimmune or microangiopathic hemolysis. Red cell production may be diminished by bone marrow infiltration, marrow necrosis, hemophagocytosis, myelofibrosis, deficiency of erythropoietic cofactors (folic acid, vitamin B12, iron), or infections. These mechanisms of anemia are much more prevalent in hematologic malignancies, but it is always important to identify them, because specific therapeutic intervention can be effective. However, cancer-associated anemia is often delineated by the more general features of the so-called "anemia of chronic disorders" (ACD). ACD is a cylokine-driven condition characterized by inadequate production of erythropoictin, inhibition of the proliferation of erythroid progenitor cells in the bone marrow and disturbances of iron utilization (Sears 1992; Means et al. 1992).

The patient's hematologic parameters at baseline may also be of importance. Patients with more severe anemia and more needs for transfusion presumably have a lower probability of achieving a target hematocrit. Pretreatment hematocrit was an important factor when rIEpo was given for the prevention of anemia (Crawford el al. 1994) but no longer when it was given after anemia was well-established (Ludwig et al. 1994). This has been very well illustrated in animal studies in which rHEpo was much more "efficient" when it was started before the administration of 5-FU, because it could then increase the hematocrit better while myelosuppression was not occurring yet (Matsumolo et al. 1990).

Other factors have been examined (Table 2). Age and sex have not been reported to influence response. Except when there is major invasion by 
cancer cells and limited residual normal hematopoiesis, marrow involvement by the tumor does not appear to limit the efficacy of rHEpo (Abels 1992: Oster et al. 199()). The type of tumor has generally not influenced the response rate, provided that no other specific mechanism of anemia is at work. Patients with multiple myeloma or low-grade lymphoma apparently have similar response rates (Österborg et al. 1996; Cazzola et al. 1995). Although there were no apparent diflerences between hematologic and nonhematologic malignancies in the largest study published (Abels 1992), there has been a suggestion that patients with breast or colon cancer (Ludwig et al. 1993a), but not those with squamous cell carcinomal (Ludwig et al. 1993h), may respond less well than patients with myelonta. Ilowever. these discrepancies most likely retale to differences in clicmolderapy duration and intensily among them.

\section{Chamotherapy-related fuctors}

Chemotherapy may also hamper response (Table 2). Anemia in cancer patients is often caused or aggravated by therapy with antineoplastic agents. In particular, treatment with platinum, but not with other chemotherapeutic agents, has been associated with impairment of erythropoictin production (Wood et al. 1995). Patients who have been heavily pretreated with chemotherapy usually experience severe stem cell damage that should considerably interfere with response to rHEpo. Indeed, the poorer response obtained in patients with lower platelet counts probably just indicates that (Österborg et al. 1996; Cazzola et al. 1995).

For patients treated concomitantly with chemotherapy. there is no marked difference between those receiving platinum-based regimens (Markman et al. 1993; Cascinu et al. 1994) and those receiving other forms of chemotherapy (Carzolat et al. 1992; Österborg el al. 1996; Carzola el al. 1995). A multicenter study showed the same Hb response (speed and magnitude) in pitients receiving platinum-based vi other foms of chemotherapy (Pawlicki et al. 1997). In the largest stucly published (Abels 1992), patients receiving platinum-based chemotherapy responded more rapidly than those receiving other combinations but the overall response rate was similar in the two groups. However, dose intensity of the two forms of chemotherapy was not assessed and it is therefore impossible to compare the degrees of myclosuppression induced by chemotherapy and thus the capacity of rHEpo to overcome it. Patients receiving chemotherapy of moderate intensity respond as well as those not receiving concomitant chemotherapy (Abels 1992). It is, however, probable that more intensive chemotherapy regimens would be associated with lower response rates. In particular, rHEpo therapy is not capable to stimulate erythropoiesis in the early period following intensificd chemotherapy with autologous bone marrow transplantation (Link et al. 1994).

On the other laund, surgery or complications of ehemotherapy, such as inflammation, infections or bleeding, may have a major negative impact upon response (Table 2). Chronic or acute blecding is a frequent complication of cancer, and this is particularly true in thrombocytopenic patients. Surgery is often followed by a transient loss of response to rHEpo, not only because it may be complicated by significant blood losses, but also because postoperative erythropoiesis is limited by the inllammatory effect of surgery on iron mctabolism that impairs iron reutilization (Biesma ct al. 1995). Any

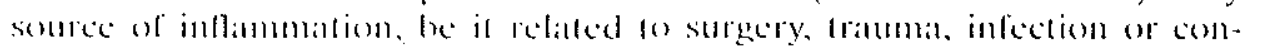
comitant disorders will interfere with response to rllepo. In particular, inlections have been shown to caluse hyporesponsiveness to rHEpo in patients with the anemia of renal failure (Danielson et al. 1995). Infections occur frequently in cancer patients receiving chemotherapy. This will slow or totally prevent response at the beginning of rHEpo therapy, as well as abrogate response when the target Hb is being maintained with lower doses, requiring higher doses to be started again.

\section{Functional iron deficiency}

Functional iron deficiency is a major factor limiting the efficacy of rHEpo therapy (Table 2). It is defined as an iron deficit in the functional erythroid compartment, the result of an imbalance between iron needs in the erythroid marrow and iron supply (Fig. 1). This may occur even in the presence of large iron stores, when storage iron release is inadequate. Iron requirements are determined by the overall level of erythropoietic activity and iron availability depends on the level of iron stores and their rate of mobilization. Functional iron deficiency can occur before rHEpo is started, either because iron stores are absent (true iron deficiency) or becaluse storage iron release is impaired, a typical feature of the anemia of elronic disorders (Fillet et al. 1989). It can also develop in the course of erythropoietin therapy when iron stores become progressively exhausted or, more frequenuly, when the increased iron needs of an expanding erythroid marrow cannot be matched by sufficient mobilization of often enlarged iron stores. Indect, the vast majority of renal failure patients treated with rHEpo develop functional iron deficiency that limits seriously their erythropoietic response (Macdougall 1999). Although this has not been specifically examined in cancer patients treated with rHEpo, there is every reason to believe that its prevalence is very high in this setting als well.

Functional iron deficiency is best diagnosed by a percentage of reticulocyles with a hemoglobin content lower than 26pg (Brugnara et al. 1994; 
Normal

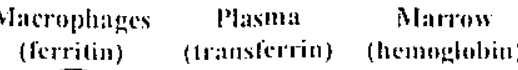

\section{Anemia of chronic disorder}

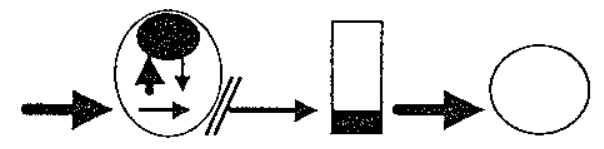

\section{rHuEpo}

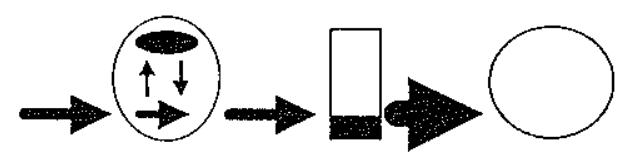

\section{$\mathrm{ACD}+\mathrm{rHuEpo}$}

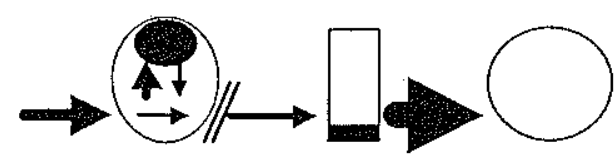

Fig. 1. Iron metabolism in various conditions illustrates lunctional iron deficiency A. Normal: when senescent red cells are phagocylosed (1) by macrophages, iron is recycled into a transit pool (2); part is stored as ferritin (hatched area) (3) and the rest is released (4) to plasma transferrin (5); iron is then taken up (6) by the erythroid marrow (7) to produce normal red cells. Iron supply (4) by storage cells matches iron demand $(6)$ by the erythroid marrow and transferrin remains adequately $(20-40 \%)$ saturated (black filling) by iron (5).

B. Anemia of chronic disorder $(A C D)$ : iron release by macroplages is blocked and more iron is stored an ferritin within these cells. Iron supply can no longer match iron demand by the erythroid marrow: transferrin saturation decreases $(<20 \%)$, the erythroid marrow becomes functionally iron deficient and new red cells alte hypochromic.

C. Treament with rhuEpo: the erythroid marrow expands upon intense stimulation by erythropoietin. Its increased demand for iron cannol be matched by storage iron releatse: transferrin saturation clecreases $(<20 \%)$, the erythroid marow becomes functionally iron deficient and new red celts are hypochromic.

D. $\triangle C D$ treated with rhuEpo: impaired iron supply and increased iron demand combine to decrease transferrin saluration and cause functional iron deficiency
Brugnara 1948) or a pereentage of hypochromic red cells greater than $10 \%$ (Macdougall et al. 1992), both parameters calculated by some automated hematologic cell counters. Alternatively, it can also be suspected when transferrin saturation falls below $20 \%$. On the other hand, serum ferritin is of very limited value, because it only gives an evaluation of iron stores without providing any hint on how these stores can be mobilized (Kooistra et al. 1991). Bccause there is some concern that tumor cells may need iron for optimal growth (Weinberg 1996), routine iron supplementation of all cancer patients receiving rHEpo is not recommended. The same is true for oral as well as intavenous iron supplementation. However, this should be balaned with the lace that translusion of one red blood edl unit also provides a large amount $(20) \mathrm{mg}$ ) of iron. Iron supplements should be given when absolute iron deficiency is suspected, i.c. when serum ferritin is below $40-100 \mu \mathrm{g} / \mathrm{L}$, a level associated with absence of iron stores in the anemia of chronic disorders. Otherwise, iron supplements should be given when the transferrin saturation is below $20 \%$ or the pereentage of hypochromic red cells greater than $10 \%$ and may be discontinued when they stabilize within the normal range. The experience in iron-replete renal failure patients has clearly indicated that oral iron supplementation is only marginally superior to no iron (Macdougall et al. 1996) but that intravenous iron both substantially improves response when rHEpo therapy is instituted (Macdougall et al. 1996) and allows considerable (in the order of $40 \%$ ) reduction in rHEpo dose requirements during the maintenance phase (Fishbane et al. 1995; Besarab et al. 2000). The safety profile (Sundex-Plassmann et al. 1997) of iron saccharate, an iron complex taken up by reticuloendothelial cells, makes it the preferred intravenous compound over iron dextran (more anaphylactic reactions) or iron gluconate (more toxicity due to free iron release) (Drueke et al. 1997). Iron usage has not been energetically pursued in clinical trials of rHEpo in cancer patients and was generally left to the discretion of the individual investigator. This was based on the false perception that cancer patients do not really need iron together with erythropoictin because their iron stores (ferritin) are not decreased. In addition, iron has only been given orally, a method proved to be of litte efficacy in renal failure patients and presumably even less effeclive in cancer patients because of impaired iron absorption, another characceristic of the ancmia of chronic disorders (Scars 1992; Means et al. 1992). The elficacy of indravenous iron alter failure of oral fron to correct functional iron deficiency and improve anemia has been well documented in juvenile chronic arthritis, another form of anemia of chronic disorder (Martini et al. 1994). Although this has not been formally studied in the anemia of cancer, intravenous administration of $100 \mathrm{mg}$ elemental iron every week or $200 \mathrm{mg}$ every other week will ensure the best utilization of any given dose of rHEpo. Future clinical trials should investigate the use of intravenous iron in cancer patients treated with rHEpo to demonstrate greater efficacy and/or lower erythropoietin requirements. 


\section{Predictive models}

Introduction

Because response rates vary considerably among patients treated similarly and clinical efficacy cannot be assessed before wceks of treatment, identification of early predictors of response would be of major interest. The use of such prognostic factors of response could help provide the benefits of rHEpo therapy to as many anemic cancer patients as possible, while avoiding prolonged ineffective use of an expensive medication.

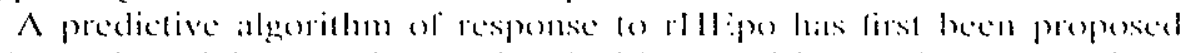
in the setting of the anemia associated with renal failure (ligg. 2) (Beguin el al. 199.3b). The best prediction by baschine parameters only wats oblatined with pretreatment soluble transferrin receptor (sTTR) and bibrinogen. Serum s'TRR represents a guantitative measure of erythropoietic activity (Huebers et al. $[(9)(0)$ and is also increased when functional irom deficiency develops (Stikne et al. 1990). It can now be measured by several commercial immunoissilys. There was a $100 \%$ response rate when both sTfR and fibrinogen were low. versus only $29 \%$ when they were both high, and $67 \%$ when one was low and the other high. Changes of STfR after 2 weeks of treatment were also predictive. When the 2 -week sTfR increment was $\geq 20 \%$, the response rate was $96 \%$. When sTfR increment was $<20 \%$, the response rate was $100 \%$ when baseline sTfR was low and fibrinogen normal, $12 \%$ when baseline fibrinogen was elevated and $62 \%$ when baseline fibrinogen was normal but baseline sTfR high. These prognostic factors illustrate the importance of the early

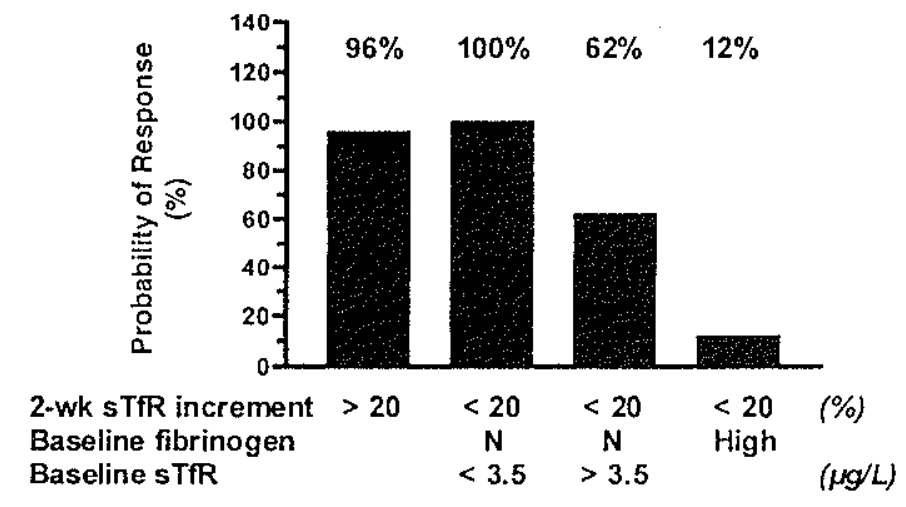

Fig. 2. Prediction of response to rHuEpo in the anemia of renal failure by baseline sTfR (an indicator of functional iron deficiency), baseline fibrinogen (a parameter of inflammation) and the 2-wk sTfR increment (a marker of increasing erythropoietic activity) (Beguin et al. 1993b) erythropoietic response (changes of sTRR levels), subclinical infammation (fibrinogen) and functional iron deficiency (baseline sTfR).

\section{Baseline parameters}

Theoretically, cancer patients with a defect in their capacity to produce Epo would be more likely to respond to rHEpo than those with adequate serum Epo levels for their degree of ancmial. As Epo levels must be interpreted in relation to the degree of anemia, the ration of observed-to-predieted Epo

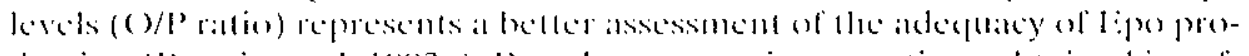
dection (Bceguin el al. 1993a). Based on regression equations obtained in refcrence subjects, predicted log (Epo) values can be derived for each Het, and O/P ratios of observed-1o-predicted values can be calculated $(95 \%$ confidence limits $(1.8()-1.20)$ (Beguin el al. 1993at). In patients with hematologic malignancies. it has been observed that low bascline serum tape levels

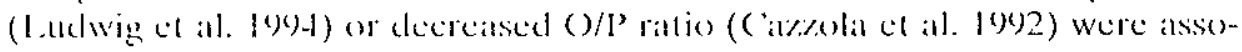
ciated with a significantly higher probability of response. This has been confirmed in large multicenter trials in patients with multiple mycloma or non-Hodgkin's lymphoma (Österborg et al. 1996; Cazzola et al. 1995). An $\mathrm{O} / \mathrm{P}$ ratio $<0.9$ was found to be associated with high response rates, whereas patients with an O/P ratio $>0.9$ rarely benefited from therapy (Cazzola et al. 1996). However, studies in patients with solid tumors have failed to confirm such a consistent predictive value of baseline Epo even when Epo deficiency was demonstrated in all or part of the patients (Abels 1992; Cascinu et al. 1994: Platanias ct al. 1991; Ponchio et al. 1992; Oberhoff et al. 1998), although a study aiming at preventing anemia in patients with ovarian carcinoma andergoing platinum-based chemotherapy showed a trend for lower translusion needs in those with an O/P ratio <0.8 (ten Bokkel Huinink et al. 1998). Of importance, in patients treated with chemotherapy, serum Epo should be evaluated just prior to chemolherapy for its interpretation to be valid (Fig. 3). Indeed, without any change in hematocrit, serum Epo may be inappropriatcly elevated in the two weeks after chemotherapy compared to pre-chemolherapy values, most probably becanse myclosuppression then decreases Epo utilization by target cells (Beguin et al. 1991; Cazzola et al. 1998). Therefore, it cannot be excluded that the failure to predict response in solid tumor patients may just be related to an inadequate timing of serum Epo sampling.

Other baseline parameters have been examined as possible predictors of response. Pretreatment hematocrit is of course an important factor when rHEpo is given for the prevention of anemia (Crawford et al. 1994) but is no longer helpful when it is given after anemia is well established (Ludwig et al. 1994). Other measurements of erythropoietic activity, such as the reticulocyte count or STfR levels were not predictive of response (Ludwig et al. 
Values expressed as \% of baseline

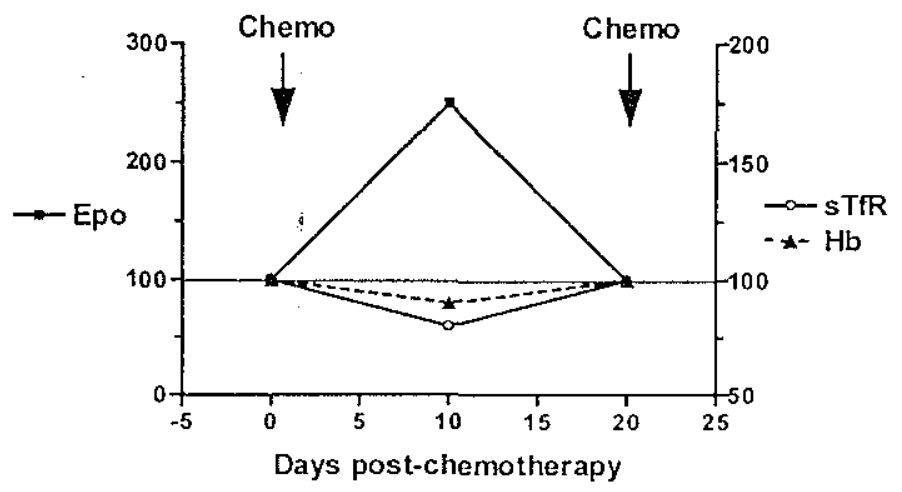

Fig. 3. Changes in serum Epo, Hb and sTlR alter a chemotherapy cycle. Chemotherapy transiently causes an increase in serum Epo levels that is disproportionate to the degrec of ancmia

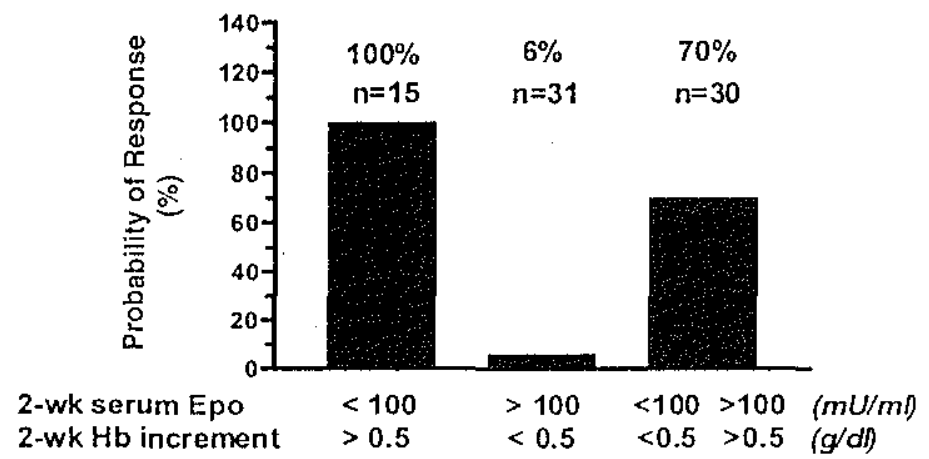

Fig. 4. Prediction of response io rluEpo in the ancmia of eancer by the week ? absolute serum Epo level and the 2-wk Hb increment (Ludwig et al. 1994)

1994). Only large doses of rHuEpo can overcome the strong inhibition of erythropoiesis induced by such cytokines as IL-1, TNF- $\alpha$ and IFN- $\gamma$. Ludwig et al. (1994) examined the possible predictive values of serum levels of these cytokines, but the results were disappointing. This is not entirely surprising since serum levels of these cylokines may not be relevant. whereas local intramedullary levels may be much more important but are very difficult to evaluante.

\section{Larly changes in erythropoietic parameters}

Early changes in parameters of erythropoictic activity observed after two weeks of treatment could be more informative. A rapid elevation of hemoglobin levels often predicted a good probability of later response (Ludwig et al. 1994; Henry et al. 1995; Cazzola et al. 1995). An increase of reticulocyte counts by $\geq 40000 / \mu 1$ from baseline to week 2 or 4 appeared to be prediclive of response but its discriminative power was weak (Henry ef al. 1995). In several studies, hemalologic response to rHEpo was strongly atssociated with early increases of sTRR levels after 1-2 weeks of treatment (Ponchio et al. 1992: ("arolal el al. 1992, 199(1). Ludwig et al. (1994) condueted the most thorough analysis and found that increases of hemoglobin, sTTR and reticulocyles, as well as decreases of serum Epo, ferritin, iron, C-reactive protein or neopterin after two wecks were all correlated with response.

\section{Predictive algorithms based on early changes}

Various models have sought to combine the predictive power of several parameters. In a study including similar numbers of patients with solid tumors or hematologic malignancies (Ludwig et al. 1994), if after 2 weeks of therapy Epo was $>100 \mathrm{mU} / \mathrm{ml}$ and hemoglobin had not increased by at least $0.5 \mathrm{~g} / \mathrm{dL}$, there was a $94 \%$ probability of unresponsivencss; otherwise, response was likely in $80 \%$ of the patients. If serum Epo was $<100 \mathrm{mU} / \mathrm{ml}$ and hemoglobin concentration had increased by $\geq 0.5 \mathrm{~g} / \mathrm{dL}$, the probability of responses was $100 \%$ : otherwise, the probability of failure was $62 \%$. However, $34 / 80$ patients did not fall into any of these two categories and, thus, prediction was valid only in a little more than half of them. The predictive value of a decrease in serum Epo levels may have 1wo explanations. Endogenous serum Epo could decrease as the hematocrit rose in responders, but the magnitude of the hematocrit changes by 2 weeks seemed to be too small for that. On the other hand, Epo could be utilized by an expanding erythroid marrow or conversely accumulate in non-responders, but it cannot be excluded that these later patients were receiving more intensive chemotherapy than others and thus be more likely to have inappropriate increases of endogenous serum Epo values (Beguin et al. 1991; Cazzola et al. 1998). Alternatively, a serum ferritin value $\geq 400 \mathrm{ng} / \mathrm{ml}$ after 2 weeks predicted for failure in $88 \%$ of the cases, whereas serum ferritin levels $<400 \mathrm{ng} / \mathrm{ml}$ predicted for success in $72 \%$ of the cases. However, the specific culpoint of $400 \mathrm{ng} / \mathrm{ml}$ cannot be extrapolated to other patients. because it depends so much on the previous transfusion history.

In a subset of patients from a large multicenter study (Abels 1992), some pediction of response could be derived from changes observed in reticulo- 
cyles and hemoglobin from baseline to week 2 of themapy (lig. 5) (Henry ed al. 1995). Among patients not receiving chemotherapy (Fig. 5A), the response rate was poor when the 2 -week increment of hemoglobin level was $<0.5 \mathrm{~g} / \mathrm{dL}$, but it was excellent when the hemoglobin level or reticulocyte count increased by $\geq 0.5 \mathrm{~g} / \mathrm{dL}$ or $\geq 40000 / \mu \mathrm{L}$, respectively. The predictive power of these parameters was much less substantial when the hemoglobin increased

\section{A}

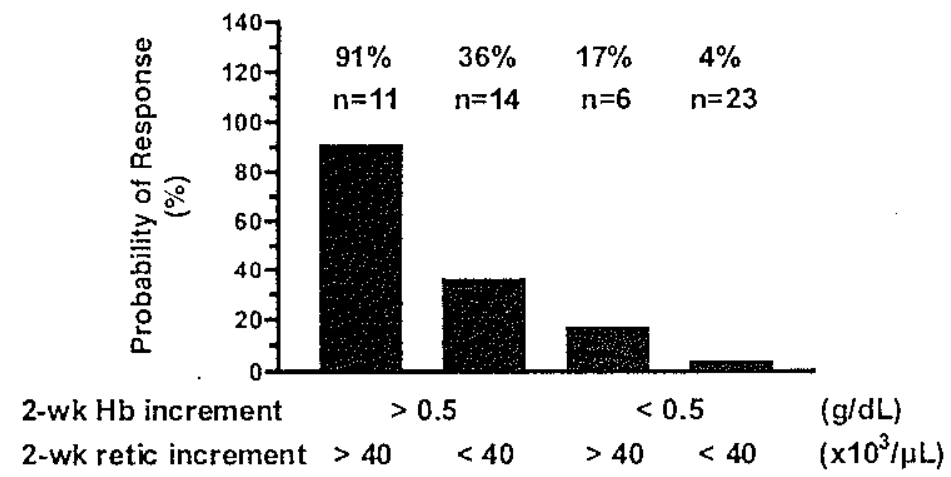

B

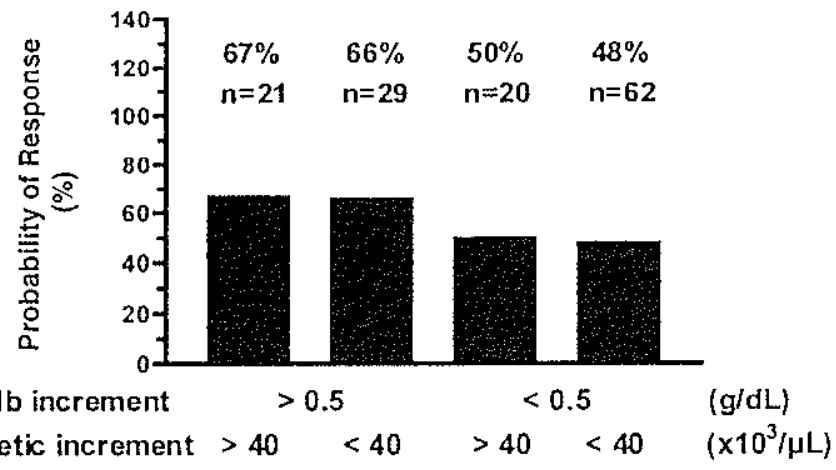

Fig. 5. Prediction of response to rHuEpo in the anemia of eancer by the 2-wk Ho and reticulocyte increments (Henry et al. 1995). A good prediction can be obtained in palients not receiving chemotherapy $(A)$ but not in those receiving chemo- by $\geq 0.5 \mathrm{~g} / \mathrm{dL}$ but ha reticulocyte elevation was smaller. Adequate prediction of response could not be provided on the basis of $\mathrm{Hb}$ and reticulocyte changes in patients receiving concomitant chemotherapy (Fig. 5B). Although some improvement in forecast could be obtained in patients increasing their hemoglobin by $\geq 1 \mathrm{~g} / \mathrm{dL}$ after 4 weeks of treatment, predicting response on the basis of the response itself may appear to be trivial.

\section{Predictive algorit/ms based on a combination of baseline parameters and early changes}

A combination of baseline parameters and early changes observed after 2 weeks of rHEpo may provide another uselul approach. Among evaluable patients treated in a large multicenter study (Cazzola et al. 1995), the failure rate was almost $90 \%$ when baseline serum O/P Epo was higher than 0.9 or when serum $O / P$ Epo was less than 0.9 but the hemoglobin increment by week 2 was $<0.3 \mathrm{~g} / \mathrm{dL}$ (Fig. (6). On the other hand, the suecess rate was around $90 \%$ when baseline serum O/P Epo was less than 0.9 and hemoglobin increased by $\geq 0.3 \mathrm{~g} / \mathrm{d}$. Similar findings were obtained in a smaller study in children with solid tumors: an $\mathrm{O} / \mathrm{P}$ ratio $<1.0$ at baseline and a hemoglobin increment $>0.5 \mathrm{~g} / \mathrm{dL}$ after 2 weeks were associated with higher response rates (Leon et al. 1998). In another large single-center study (Cazzola et al. 1996), the combined use of baseline serum Epo and the 2-week increment of sTfR proved to be very powerful (Fig. 7 ). Only $18 \%$ of patients with a baseline serum Epo greater than $100 \mathrm{mU} / \mathrm{ml}$ responded to treatment, and only $29 \%$ responded when the baseline serum Epo was $<100 \mathrm{mU} / \mathrm{mL}$ but the 2-week sTfR increment was less than $25 \%$. On the other hand, the response rate was $96 \%$ among patients with a low bascline serum Epo and a substantial sTfR elevation.

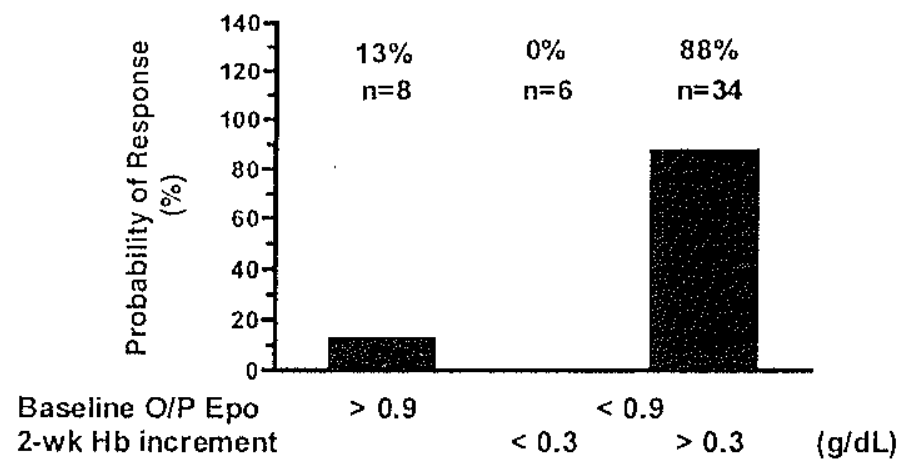

Fig. 6. Prediction of response to rHuEpo in the anemia associated with lymphoma or multiple myeloma by the baseline observed/predicted serum Epo ratio and the

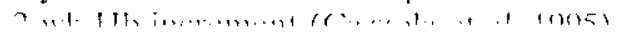




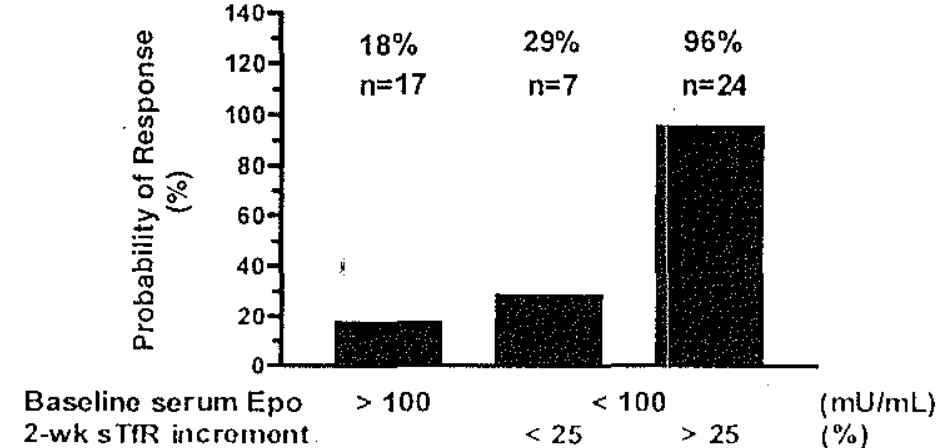

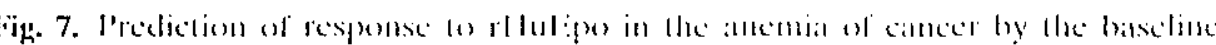
serum Epo level and the 2-wk sTTR increment (Carzolat et al. 1996)

\section{Applicability of predictive factors}

There are a number of theoretical reasons why some or all of these parameters might not be of value in certain situations (Table 3). While evaluation of endogenous Epo production may be relevant in various forms of anemia, it is of no interest in subjects in whom the aim of rHEpo therapy is to prevent an anemia that is not yet present, in those in whom better tumor oxygenation before radiotherapy or induction of fetal hemoglobin is sought, or in disorders characterized by universal Epo deficiency. Even among cancer patients, whereas low baseline serum Epo levels or decreased observed-topredicted Epo levels $(\mathrm{O} / \mathrm{P}$ ratio) were associated with a significantly higher probability of response in patients with hematologic malignancies (Ludwig et al. 1994; Österborg et al. 1996; Carrola et al. 1995, 1996), this was ustally not the case in patients with solid tumors (Abels 1992; Cascinu et al. 1994). On the other hand, hemoglobin increments alter 2 weeks of treatment may be of value in steady state patients, but are of litte help in transfused patients and in those in whom rHEpo is intended to prevent the occurrence of severe ancmia but cannot avert some decrease in hemoglobin induced by phlebotomy or myelosuppressive treatments. Finally, changes in parameters directly reflecting erythropoictic activity, i.e. reticulocyle counts and sTfR, may be the most appropriate. However, changes in reticulocyte counts may simply reflect output of shift reticulocytes and not true expansion of erythropoiesis, and often have not been found to be a good indicator of response (Beguin et al. 1993b; Ludwig et al. 1994). Although sTfR levels represent the best quantitative measurement of total crythropoictic activity, they may also increase secondary to functional iron deficiency (Huebers et al. 1990). In addition, particularly in patients treated with chemotherapy, the timing of the evaluation of these parameters relative to chemotherapy may be critical for their interpretation. For instance, mealsuring serum Epo after chemotherapy
Table 3. Theoretical value (yes = probably of value; no = probably of no value) of potential predictors of response to $\mathrm{rHuEpo}$ in various settings according to the indication for therapy (see text for discussion)

\begin{tabular}{|c|c|c|c|}
\hline & $\begin{array}{l}\text { Baseline } \\
\text { Epo or } \\
\text { O/P ratio }\end{array}$ & $\begin{array}{l}\text { 2-wk Hb } \\
\text { increment }\end{array}$ & $\begin{array}{l}\text { 2-wk } \\
\text { retic/sTfR } \\
\text { increnent }\end{array}$ \\
\hline 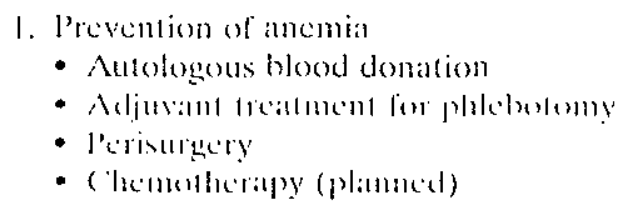 & $\begin{array}{l}\text { No } \\
\text { No } \\
\text { No) } \\
\text { Yesis (2) }\end{array}$ & $\begin{array}{l}N_{0} \\
N_{1} \\
N_{0}(1) \\
N_{0}\end{array}$ & $\begin{array}{l}\text { Yes } \\
\text { Yes } \\
\text { No(1) } \\
\text { No }\end{array}$ \\
\hline $\begin{array}{l}\text { 2. Correction of untransfused anemia } \\
\text { - AIDS, inflammatory diseases, cancer, } \\
\text { MDS, organ transplantation } \\
\text { - Chemotherapy (ongoing) }\end{array}$ & $\begin{array}{l}\text { Yes (2) } \\
\text { Yes (2) }\end{array}$ & $\begin{array}{l}\text { Yes } \\
\text { Yes (3) }\end{array}$ & $\begin{array}{l}\text { Yes } \\
\text { Yes (3) }\end{array}$ \\
\hline $\begin{array}{l}\text { 3. Reduction in transfusion requirements } \\
\text { - AIDS, inflammatory diseases, cancer, } \\
\text { MDS, organ transplantation } \\
\text { - Chemotherapy (ongoing) } \\
\text { - Prematurity } \\
\text { - Allogencic stem cell transplantation }\end{array}$ & $\begin{array}{l}\text { Yes (2) } \\
\text { Ycs (2) } \\
\text { No (4) } \\
\text { No (4) }\end{array}$ & $\begin{array}{l}\text { No } \\
\text { No } \\
\text { No } \\
\text { No }\end{array}$ & $\begin{array}{l}\text { Yes } \\
\text { Yes (3) } \\
\text { Yes } \\
\text { No }\end{array}$ \\
\hline $\begin{array}{l}\text { 4. Miscellaneous } \\
\text { - Radiotherapy } \\
\text { - Orthostatic lypotension } \\
\text { - Induction of fetal } \mathrm{Hb}\end{array}$ & $\begin{array}{l}\text { No } \\
\text { No } \\
\text { No }\end{array}$ & $\begin{array}{l}\text { Yes } \\
\text { Yes } \\
\text { No }\end{array}$ & $\begin{array}{l}\text { Yes } \\
\text { Yes } \\
\text { No }\end{array}$ \\
\hline
\end{tabular}

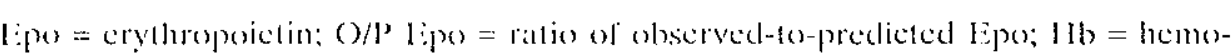
ghobin; retic = reticulocyles; sTTR = soluble transferrin receptor.

(1) Treatment too short to be modified by changes in erythropoictic parameters.

(2) Epo deficiency in some forms of cancer (1ymploma, myeloma, some MDS) and chemotherapy (cisplatin).

(3) Timing of sample for measurement of predictor may be critical (see text)

(4) Nol a real predictor hecatse Epo deficiency is observed in virtually all patients.

may yield elevated levels compared to pre-chemotherapy values, without any change in hematocrit (Beguin et al. 1991).

\section{Conclusion}

Several algorithms have been proposed for patients with the anemia of cancer (Table 4). Their sensitivity (how well the algorithm identifies all those 
who will respond) and specificity (how well the algorithm excludes all those who will fail), and thus their overall efficacy, vary considerably. In the study conducted by Ludwig (Ludwig et al. 1994), when one tries primarily to identify non-responders instead of responders, sensitivity and overall accuracy can be increased from $42 \%$ and $70 \%, 1076 \%$ and $86 \%$, respectively. Overall accuracy is not improved by doing so in the study conducted by Henry in patients receiving chemotherapy, because enhaneed sensitivity $(54 \%)$ is compensilled by diminished specilicity $(52 \%)$. The positive predictive value (probability of response in these predicted to respond) of the algorithms is usually better than their newative predietive value (probability of failure in those predicted to fail).

The best algorithms appear to be those combining an assessment of the adequacy of endogenous Epo production (at least in hematologic malignancies) together with some early indicators of erythropoietic marrow response (changes in hemoglobin or STRR). The following scheme can be proposed in practice (Fig. S). Baseline serum Epo shoukd be measured at baseline in patients with hematologic malignancies: treatment should not be initiated if endogenous serum Epo is above $100 \mathrm{mU} / \mathrm{mL}$ (or $200 \mathrm{mU} / \mathrm{mL}$ in severely anemic patients) or the O/P ratio is $>0.9$. Erythropoietic response should be

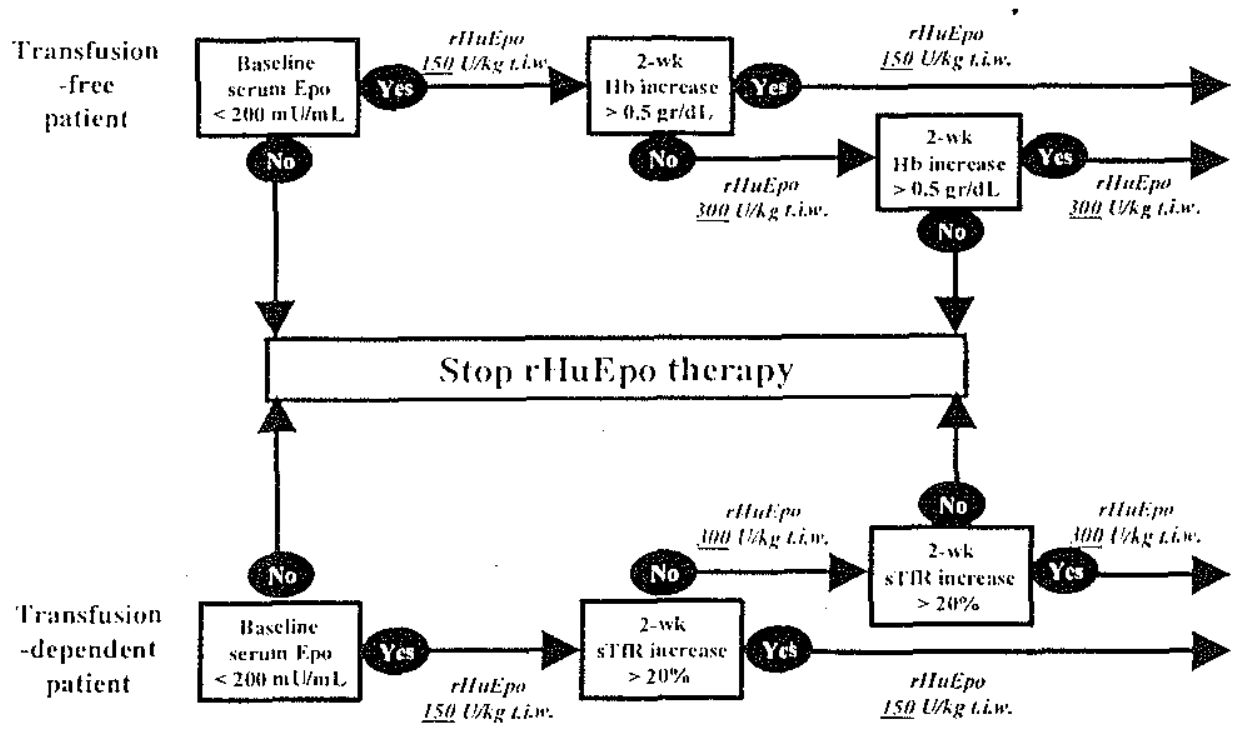

Fig. 8. Practical use of algorithms for prediction of response in cancer patients treated with rHuEpo, based on baseline endogenous Epo level and an early (2-wk) indicator of increased erythropoictic activity. The first step (baseline Epo) could be omitted in solid tumor patients. The only difference between untransfused and transfised patients is that the 2-wk Hb increment cannot be used in transfusion-

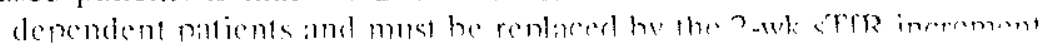


assessed after 2 weeks. In untransfused patients. if the Ho has increased by at least $0.5 \mathrm{~g} / \mathrm{dL}$, continue treatment; otherwise double the dose and definitively discontinue rHEpo after 2 additional weeks if $\mathrm{Hb}$ has not increased by at least $0.3 \mathrm{~g} / \mathrm{dL}$. In transfused patients, if sTfR has increased by at least $20 \%$. continue treatment; otherwise double the dose and delinitively discontinue rHEpo after 2 additional weeks if sTIR has not increased by at Icast $20 \%$. It is. of course, critical that all preventable caluses of failure are identified prospectively and corrected, or else no predictive nodel will be valid. In particular this includes vigorous iron supply and energetic tratment of intercurrem complications sesch as infections and bleceding.

\section{References}

Abets RI (1992) Use of recombinant buman erythropoictin in the treatment of incmia in paticnts who have eneer. Semin Onco] [9: 29-35

Beguin Y (1996) Erythropoictin and the anemia of cancer. Acta Clin Belg 51: 36-52

Beguin $Y$ (1998) Prediction of response to treatment with recombinant human erythropoietin in anaemia associated with cancer. Med Oncol 15 (Suppl 1): 3846

Beguin Y, Clemons G, Pootrakul P, Fillet G (1993a) Quantitative assessment ol erythropoiesis and functional classilication of anemia based on measurements of serum transferrin receptor and erythropoietin. Blood \$1: 1067-1076

Beguin Y, Clemons GK. Oris R, Fillet G (1991) Circulating erythropoietin levels after bone marrow transplantation: Inappropriate response to anemia in allogeneic transplants. Blood 77: 868-873

Beguin Y, Loo M, R'Zik S. Sautois B, Lejeune F, Rorive G, Fillet G (199,3b) Early prediction of response 10 recombinant human erylhropoietin in patients with the

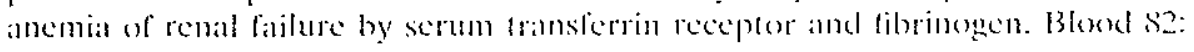
$20 !()-2016$

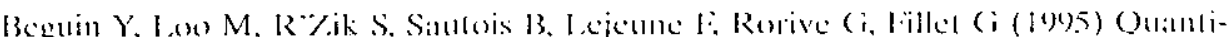
taltive assessment of erythropoiesis in hacmodialysis patients demonstrates gradual expansion of erybluoblasts during constant treatment with recombinant human erythropoietin. Br. J Hakmatol 89: 17-2.3

Besamab A, Amin N. Ahsan M, Vogel SE. Zil\%uwa (i, Frinal S, Kal\%a JJ, Anandan JV. Gupta $A(2000)$ Optimization of epoctin therapy with intravenous iron thetaty in hemodialysis patients. J Am Soc Nephrol 11: 530-538

Biesma DH, van de Wiel A, Beguin Y, Kraaijenhagen RJ, Marx JJ (199.5) Postoperative erythropoiesis is tinited by the inflammatory effect of surgery on iron metabolism. Eur J Clin Invest 25: 383-389

Breymann C, Bauer C, Major A, Zimmermann R, Gautschi K. Huch A, Huch R (1996) Optimal timing of repeated rh-erythropoietin administration improves its effectiveness in stimulating erythropoiesis in healthy volunteers. $\mathrm{Br} \mathrm{J}$ Haematol 92: $295-301$

Brugnam $C(1998)$ Use of reticulocyce cellutar indices in the diagnosis and treatment of hematological disorders. In I Clin I ah Res 2s: 1 . 1 I
Brugnaral C. Colella GM, Cremins J. Langley RC Jr. Schneider TJ. Rutherford CJ, Goldberg MA (1994) Effects of subcutaneous recombinant human erythropoictin in normal subjects: development of decreased reticulocyte hemoglobin content and iron-deficient erythropoiesis. J Lab Clin Med 123: 660-667

Cascinu S. Fedeli A. Del Ferro E, Luzi Fedeli S, Catalano G (1994) Recombinant human erythropoietin treatment in cisplatin-associated anemia: a randomized, double-blind trial witle placebo. J Clin Oncol 12: 1058-1062

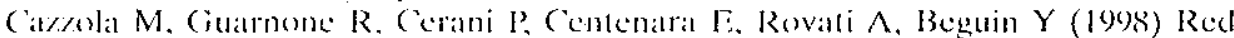
blool cell precursor mass as an independent dekerminant of serum erythropoi(in level. Blond (9)1: 21.39 .2145

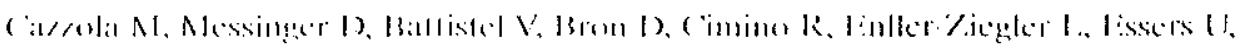
(ircil R. Gressi A, Janger (i, LeMevel A, Najman A, Silingardi V, Spriano M, van Ihof $\wedge$. Rhmes $B$ (1995) Recombinant human erythopoictin in the anemia associated with multiple myeloma or non-Hodgkin's lymphoma: dose linding and identification of predictors of response. Blood \$6: 4446-4453

Carzolal M. Ponchio L. Beguin Y, Rosti V. Bergamaschi G, Liberato NL, Fregoni V, Nalli G. Barosi G, Ascaur E (1\%92) Subcutancous crythropoictin for treatment of refractory anemia in hemalologic disorders. Results of a phase $1 / 11$ clinical trial. Blood 7): 29-37

Cazzola M. Ponchio L, Pedrotti C. Farina G, Cerani P. Lucotti C. Novella A, Rovati A. Berganaschi $G$, Beguin $Y(1996)$ Prediction of response to recombinant human erythropoietin (rHuEpo) in ancmia of malignancy. Haematologica 81: 434441

Cheung W. Minton N. Gunawardena K, Frey K (2000) The pharmacokinetics and pharmacodynamics of Epoctin alpha once weckly versus Epoetin alpha 3 times weekly. Blood 96(Suppl 1): 295a (Abstrac1)

Crawlord J, Blackwell S, Shoemaker D, Pupa MR, Mulhausen T, Herndon J, Winer E. Flynn J, Dempsey H (1994) Prevention of chemotherapy related anemia by recombinant haman erythropoictin (EPO) in paticnts with small cell lung cancer (SCLC) receiving cyclophosphamide, doxorubicin, and eloposide (CAE) chemotheralpy with (i-CSF support. Blocol is (Suppt 1): 12)a (Abstracl)

Damielson B, Beguin Y. Bommer J, Cammata B, De Broe ME. Drueke TB, Itel TH,

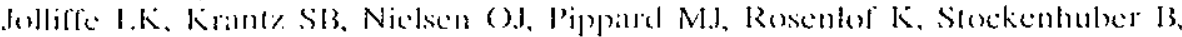
Wincarts ( ( $(995)$ R-I IulEl'() hyporesponsiveness - who and why? Nephrol Dial Transplant 10 (Suppl 2): (6)-73

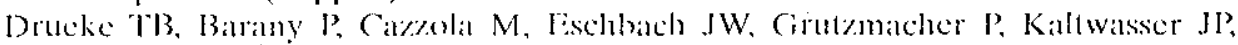

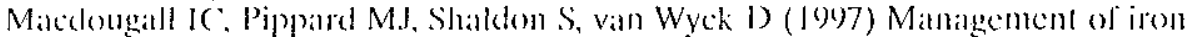
deficiency in renal anemia: guidelines for the optimal therapeutic approach in erythropoietin-treated patients. Clin Nephrol 48: $1-8$

Fillet G, Beyuin Y, Baldelli L (1989) Model of reticuloendothelial iron metabolism in humans: abnormal behavior in idiopathic hemochromatosis and in inflammation. Blood 74: $844-851$

Fishbane S. Frei GL, Maesaka J (1995) Reduction in recombinant human erythropoietin doses by the use of chronic intravenous iron supplementation. Am J Kidney Dis 26: 41-46

Gabrilove JL. Einhorn LH, Livingston RB, Winer E. Cleeland CS (1999) Onceweckly dosing of Epoctin alfa is similar to three-times-weckly dosing in increas-

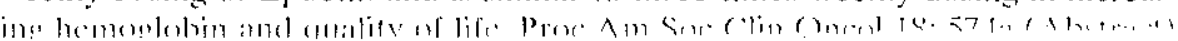


Glimelius B, Linne T, Hoffman K, Larsson L, Svensson JH, Nasman P, Svensson B, Helmers $C$ (10)8) Epoetin beta in the treatment of ancmia in patients with advanced gastrointestinal cancer. J Clin Oncol 16:434-440

Groopman JE, Itri LM (1999) Chenotherapy-induced anemial in adults: incidence and treatment. J Nall Cancer Inst 91: 1616-1634

Henry D. Abels R. Larholt K (1995) Prediction of response to recombinant human erythropoictin (r-HuEPO/epoetin-alpha) therapy in cancer patients [letter] Blood $85: 1676-1678$

Henry DH. Abels Rl (1994) Recombinant human erythropoietin in the treatment of cancer and chemolberapy-indeced anemia: Results of double-blind and openlabel follow-lip) studies. Somin Oncol 21 (Suppl 3 ): 21 - 28

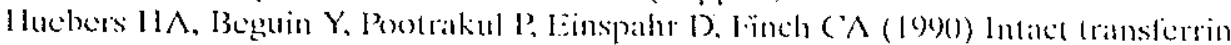
receptors in human plasma and their relation to erythropoiesis. Blood 75: 102-107

Kooistra MP, van Es A, Struyvenberg A. Marx JJ (1991) lron melabolisn in patients with the anaemia of end-stage renal disease during treatment with recombinant human erythropoictin. Br I Hacmatol 79: 6.34-6.39

Leon MP, Jimenez MM, Barona ZP. Riol DM, Castro PL, Sierrasesumaga AL (194S) |Recombinam human erythropoietin in anemial associated with pediatric cancer study of the identilication of predictors of response). An Esp Pediatr 49: 17-22

Link H, Boogaerts MA, Fauser AA, Slavin S, Reiflers J, Gorin NC, Carella AM, Mandelli F, Burdach S, Ferrani A, Linkesch W, Tura S, Bacigalupo A, Schindel F Heinrichs $H$ (1994) A controlted trial of recombinant human erylhropoietin after bone marrow transplantation. Blood 84: 3327-3335

Ludwig H, Fritz E, Leitgeb C, Krainer M, Kuhrer I, Sagaster P, Umek H (1993a) Erythropoietin treatment for chronic anemia of selected hematological malignancics and solid tumors. Ann Oncol 4: 161-167

Ludwig H, Frit\% E, Leitgeb C, Pecherstorfer M, Samonigg L, Schuster J (1994) Prediction of response to erythropoietin freatment in chronic anemia of cancer. I3lood s.4: $1056-1063$

Ludwig H, Pecherstorfer M, Leitgel) C: Frit E (1993b) Recombinant human erythropoietin for the treatment of chronic ancmia in multiple myeloma and squamous cell carcinoma. Stem Cells 11:348-355

Macdougall IC (1999) Strategies for iron supplementalion: omal versus intravenous. Kiclncy Int (Suppl) 69: S61--S660

Macdougall IC $(20(0))$ Novel erythropoiesis stimulating protein. Semin Nephrol 20: $37.5-381$

Macdougall IC, Cavill I, Hume B, Bain B, MeCiregor LE, Mekaly P. Sanders li, coles GA, Willams JD (1992) Detection of functional iron deliciency during erythropoictin treatment: al new approach. Br Med J 304: 225-226

Macdougali IC, Roberts DE, Neubert P, Dharmasena AD, Coles GA, Willians JD (1989) Phamacokinetics of recombinant human erythopoietin in patients on continuous ambulatory peritoneal dialysis. Lancet 1: 425-427

Macdougall IC, Tucker B, Thompson J, Tomson CR, Baker LR, Raine AE (1996) A randomized controlled study of iron supplementation in patients treated with crythropoictin. Kidncy lnt 50: 1694-1699

Markman M. Reichman B. Hakes T, Rubin S, Jones W, Lewis JL, Jr., Curtin J,

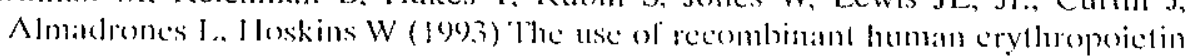
Martini A. Ravelli A, Di Fuccia G, Rosti V, Cazzola M, Barosi G (1994) Intravenous
iron therapy for severe anaemia in systemic-onset juvenile chronic arthritis. Lancel 344: 10.52-105.54

Matsumoto T, Endoh K, Kamisango K, Akamatsu K, Koizumi K, Higuchi M, Imai N, Mitsui H, Kawaguchi T (1990) Effect of recombinant human erythropoietin on anticancer drug-induced anaemia. Br J Haematol 75: 463-468

Mcians RT Jr, Krantz SB (1992) Progress in understanding the pathogenesis of the ancmia of chronic discasc. Bioxd so): $16.39-1647$

Moliterno AR, Spivat JL (1996) Anemia of cancer. Lematol Oncol Clin North Am 10: $345-36.3$

()herbuff (: Neri 13. Amikfori D), Petry KU, Camucei T, Rebmann U, Nowrousian-

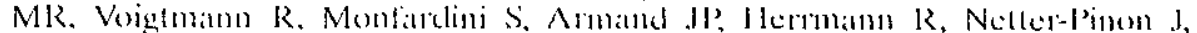
Tubitma-Mathieu N. Zwierina 11 (1998) Recombinant human erythropoictin in the treatment of chemotherapy-induced anemia and prevention of transfusion recpuirement associated with solid tumors: a randomized, controlled study. Ann . Oncol 9: 255-260

Oster W, Hermann F, Gamm H, Zeile G, Linclemann A, Muller G, Brune T, Kraemer HP, Mertelsmann R (1990) Erythropoietin for the treatment of anemia of malignancy associated with neoplastic bone marrow infiltration. J Clin Oncol 8: 956-962

Österborg A, Boogaerts MA, Cimino R, Essers U, Holowiecki J, Juliusson G, Jager G, Najman A, Peest D (1996) Recombinant human erythropoietin in transfusionclependent anemic patients with multiple myeloma and non-Hodgkin's lymphoma. A randomized multicenter study. Blood 87: 2675-2682

Paganini EP, Eschbach JW, Lazarus JM, Van Stone JC, Gimenez LF, Graber SE, Egrie JC, Okamoto DM, Goodkin DA (1995) Intravenous versus subcutaneous dosing of epoctin alfa in hemodialysis patients. Am J Kidney Dis 26: 331340

Pawlicki M, Jassem J, Bosze P, Lotan C, Kurteva GP, Siddiqui M, Kosmidis PA, Rigatos GA, Kansu E, Durkovic P, Aziz Z, Al Ictrissi H, Roth A, Cozma G (1997) $A$ multicenter study of recombinant humatn erylhopoictin (epoctin alpha) in the management of anconia in cancer paticuts receiving chemotherapy. Anticancer Drugs s: 949-957

Platimias LC, Miller CB, Miek R, Hart RD, Ozer L-1, McEvilly JM, Jones RJ, Ratain MI (1991) Treatment of elremolherapy-induced anemia with recombinant human erythroporitan in cancer patients. J Clin Oncol 9: 2021-2026

Ponchio L, Beguin Y, Furina G, Pedrazzoli P, Pedrolli C, Poggi G, Rosti V,

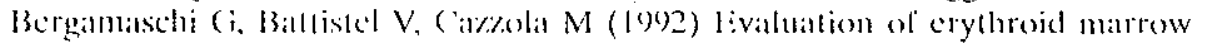
response fo recombinan heman erythropoiclin in patients with cancer anacmia. Halemallologica $77: 494-50$ )

Sears D (1992) Anemia of chronic disease. Med Clin North Am 76:567-579

Skikne BS, Flowers CH, Cook JD (1990) Serum transferrin receptor: a quantitative measure of tissue iron deficiency. Blood 75: 1870-1876

Sunder-Plassmann G, Horl WH (1997) Safety aspects of parenteral iron in patients with encl-stage renal discase. Drug Safely $17: 241-250$

ten Bokkel Huinink WW, de Swart CA, van Toom DW, Morack G, Breed WP, Hillen HF, van der Hoeven JJ, Reed NS, Fairlamb DJ, Chan SY, Godfrey KA, Kristensen GB, van Tinteren H, Elumer B (1998) Controlled multicentre study of the influence of subcutaneous reconbsinant human erythroposetin on anacmia 
and transfusion dependency in patients with ovarian carcinoma treated with platinum-based chemotherapy. Med Oncol 15: 174-182

Weinberg ED (1996) The role of iron in cancer. Eur J Cancer Prev 5: 19-36

Wood PA, Hrushesky WJ (1995) Cisplatin-associated anemia: an erythropoietin deficiency syndrome. J Clin Invest 95: 1650-1659

(amespondence: Yves Beguin, MD), Universily of I iege, Department of Hematology,

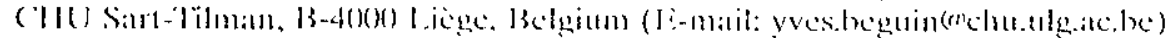

\section{Chapter XVI}

\section{rhEPO in hematopoictic stem cell mobilization, transplantation and in-vitro expansion}

\author{
S. Klusisom
}

Department of Pediatries. Huddinge University Hospital, Karolinska Institute, Stockhotm, Sweden

\section{Summary}

Various hematopoietic growth factors and cytokines are being increasingly studied in the transplant setting. They are used, not only to accelerate haematopoietic recovery after cytopenias but also as mobilizers of stem cells in donors, ex vivo expansion of stem cells and for supportive treatment during infections. All these new factors, alone or in combination, may contribute to improved regimens during transplantation. Bone marrow transplant (BMT) or peripheral blood progenitor stem cells transplant (PBSCT) recipients have in the period following transplantation a frequent need for red blood cell transfusions and, therefore, an increased risk of blood-transmitted infections. The anemia is caused mainly by myelosuppression alter high-dose chemotherapy but an impaired erythropoietin (EPO) production and an inappropriate EPO response may also contributc. Since recombinant human erythropoietin (rlhEPO) has been established as a treatment for renal anemia it has been of interest whether treatment may be of benefit in the transplantation setting. So far data do not support any transfusional benefits with the use of rhEPO after autologous transplantation. In patients receiving an allograft, especially patients with immune hemolysis after transplantation, rhEPO treatment seems to accelerate erythroid engraftment, increase hemoglobin levels, reduce red blood cell transfusions and shorten time to transfusion independence. However, the optimal dose of thEPO, the route of administration, the most effective combination with other hematopoietic growth factors, and in which patient populations cost-effective rhEPO therapy is justified are still open questions.

\section{Background}

